\title{
Sistem Pendukung Keputusan dalam Merekomendasikan Unit Terbaik di PDAM Tirta Lihou Menggunakan Metode Promethee
}

\author{
Tia Imandasari, Agus Perdana Windarto*) \\ Program Studi Sistem Informasi, STIKOM Tunas Bangsa Pematangsiantar \\ Jl. Jenderal Sudirman Blok A No.1/2/3 Pematangsiantar, Medan, Indonesia, 21127
}

\begin{abstract}
Cara sitasi: T. Imandasari, and A. P. Windarto, "Sistem Pendukung Keputusan dalam Merekomendasikan Unit Terbaik di PDAM Tirta Lihou Kabupaten Simalungun Menggunakan Metode Promethee," Jurnal Teknologi dan Sistem Komputer, vol. 5, no. 4, pp. 159-165, Okt. 2017. doi: 10.14710/jtsiskom.5.4.2017.159-165, [Online].
\end{abstract}

\begin{abstract}
This research aims to develop decision support system in determining the best production unit in PDAM Tirta Lihou, Simalungun District. The research data were sourced from the institution in 2014. The alternatives used were 34 units of production and 6 criteria as the ranking of the best production unit such as the criteria for selling of water supply (C1), evaluation of arrears achieved (C2), evaluation of leakage rate (C3), running bill evaluation (C4), number of new customers (C5) and sales / use of water per customer (C6). The method used in this research was Promethee. The research showed that the best unit in PDAM Tirta Lihou was the Tanah Jawa unit with Net Flow 0.16274. With this system, agency leaders can produce a better decision to select the best unit in a more objective way.
\end{abstract}

Keywords - Decision support system; the best unit recommendation; Promethee method; assessment of PDAM performance

\begin{abstract}
Penelitian ini bertujuan untuk mengembangkan sistem pendukung keputusan dalam menentukan unit produksi terbaik di PDAM Tirta Lihou, Kabupaten Simalungun. Data penelitian bersumber dari instansi terkait tahun 2014. Alternatif yang digunakan adalah 34 unit produksi dan 6 kriteria sebagai penilaian unit produksi terbaik, yaitu kriteria penjualan rekening khusus air (C1), evaluasi tunggakan yang dicapai (C2), evaluasi tingkat kebocoran (C3), evaluasi tagihan berjalan (C4), jumlah sambungan baru (C5) dan penjualan/pemakaian air per pelanggan (C6). Penelitian menggunakan metode Promethee. Sistem yang dikembangkan ini menunjukkan bahwa unit terbaik di PDAM Tirta Lihou adalah unit Tanah Jawa dengan nilai Net Flow 0,16274. Dengan sistem ini, pimpinan instansi dapat menghasilkan sebuah keputusan untuk memilih unit terbaik secara lebih objektif.
\end{abstract}

Kata Kunci - Sistem pendukung keputusan; rekomendasi unit terbaik; metode Promethee; penilaian kinerja PDAM

*) Penulis korespondensi (Agus Perdana Windarto) Email: agus.perdana@amiktunasbangsa.ac.id

\section{Pendahuluan}

Di dalam sebuah perusahaan, karyawan merupakan salah satu aset terpenting yang dimiliki oleh perusahaan dalam usahanya mempertahankan kelangsungan hidup, berkembang, berkemampuan untuk bersaing dan mendapatkan laba, seperti pada perusahaan air minum yang ada di Sumatera Utara yaitu PDAM Tirta Lihou. Perusahaan PDAM Tirta Lihou yang terletak di kabupaten Simalungun terdiri dari 34 unit produksi yang dibentuk untuk meningkatkan mutu pelayanan kepada masyarakat. Perusahaan PDAM Tirta Lihou dituntut untuk beradaptasi meningkatkan kualitas pelayanan ke masyarakat dan pelayanan dari penyedia sumber air bersih ke rumah-rumah masyarakat. Pada akhir tahun, setiap unit produksi memberikan laporan tentang target luaran yang telah dicapai oleh masingmasing unit. Proses penilaian tersebut dilakukan oleh pimpinan PDAM Tirta Lihou berdasarkan hasil laporan yang disampaikan. Pimpinan memberikan penilaian berdasarkan target penjualan yang dicapai sehingga masih dipengaruhi unsur subjektivitas dan dirasakan kurang mendukung proses tersebut. Apabila terjadi ketidaktepatan pimpinan dalam memberikan penilaian kepada setiap unit produksi maka penilaian yang diberikan masih bersifat tidak pasti dan tidak jelas karena dimungkinkan muncul ketidaktepatan dalam memberikan nilai dan karena adanya beberapa kriteria yang bersifat subjektif.

Beragam teknik dan aplikasi telah dikembangkan untuk menyelesaikan ketidaktepatan penilaian kinerja perusahaan, yaitu salah satunya berupa sistem pendukung keputusan (SPK). Aplikasi-aplikasi SPK untuk membantu memberikan penilaian telah dikembangkan, di antaranya untuk menentukan karyawan, mahasiswa atau guru terbaik [1]-[3], penerimaan karyawan [4], dan penilaian kinerja pegawai dan promosi pegawai [5]-[8]. Metode yang digunakan dalam aplikasi SPK tersebut adalah antara lain metode AHP di [1], [2], [9], SAW di [7]-[9], Promethee di [2]-[6], [11]-[13], TOPSIS di [9], serta Fuzzy dan FMADM di [14], [15].

Metode Promethee mempunyai kelebihan dalam proses pemeringkatan alternatif menggunakan fungsi preferensi dan bobot yang berbeda-beda [16]. Kelebihan 
ini digunakan oleh sistem pemeringkatan berdasarkan preferensi dan bobot dari kriteria-kriteria tertentu, misalnya Asmara [3] yang melakukan pemeringkatan daftar pelamar dalam penerimaan karyawan menggunakan 5 kriteria, yaitu usia pelamar, status kawin pelamar, pengalaman kerja, pendidikan terakhir dan nilai rata-rata. Penelitian lainnya tentang pemeringkatan berdasarkan preferensi adalah Hidayat [5] tentang pengambilan keputusan di bidang pemasaran, sumber daya manusia, pemilihan lokasi, atau bidang lain yang berhubungan dengan pemilihan alternatif, Gunawan dan Astuti [11] tentang perbandingan untuk masing-masing alternatif sehingga menghasilkan keluaran urutan/peringkat, Andhi [6] tentang penilaian kinerja pegawai dalam promosi museum Ranggawarsita, dan Hanifah [12] tentang penerimaan kredit usaha rakyat.

Dengan menggunakan alternatif, kriteria, dan tipe kriteria yang berbeda dengan penelitian di atas, penelitian ini bertujuan mengembangkan sistem pendukung keputusan menggunakan metode Promethee untuk melakukan pemeringkatan kinerja unit produksi terbaik secara objektif dari 34 unit produksi PDAM Tirta Lihou, Kabupaten Simalungun. Pemeringkatan ini digunakan untuk menilai kinerja dan menentukan unit produksi terbaik berdasarkan laporan target luaran yang telah dicapai oleh masing-masing unit. Kriteria yang digunakan didasarkan pada hasil wawancara dengan pihak pimpinan PDAM. Sistem ini dapat meminimalkan terjadinya risiko penilaian secara subjektif yang dilakukan oleh pimpinan yang berdampak kepada kinerja dari unit produksi tersebut.

\section{Metode Penelitian}

Penelitian ini menggunakan metode Promethee untuk membuat SPK penentuan unit produksi terbaik di PDAM Tirta Lihou. Pengumpulan data dalam penelitian ini dilakukan dengan mengambil data yang telah ada di instansi terkait dan melakukan wawancara dengan instansi PDAM Tirta Lihou. Langkah-langkah dalam perhitungan metode Promethee adalah 1) menentukan beberapa alternatif, 2) menentukan beberapa kriteria, 3) menentukan tipe penilaian (MAX/MIN), dan 4) menentukan tipe preferensi untuk setiap kriteria yang paling cocok didasarkan pada data dan pertimbangan pengambil keputusan.

Penelitian ini menggunakan data kuantitatif dengan menggunakan sumber data dan wawancara dari pihak PDAM Tirta Lihou. Data yang digunakan adalah tahun 2014 dimana data tersebut terdiri dari 30 alternatif dan 6 kriteria. Kriteria yang digunakan pada penelitian ini adalah Penjualan Rekening Air (DRD) Khusus Air (C1), Evaluasi Tunggakan yang Dicapai (C2), Evaluasi Tingkat Kebocoran (C3), Evaluasi Tagihan dari DRD Berjalan (C4), Jumlah Sambungan Baru (C5), Penjualan/ Pemakaian Air $\mathrm{m}^{3} /$ pelanggan (C6). Penentuan tipe preferensi untuk setiap kriteria ditentukan berdasarkan keuntungan dan biaya. Preferensi kriteria keuntungan adalah $\mathrm{C}$ 1, C5, dan C6. Preferensi kriteria biaya adalah C2, C3, dan C4.
Penelitian ini menggunakan 4 (empat) tipe kriteria dari kriteria dasar seperti dinyatakan dalam [17], yaitu kriteria quasi (Persamaan 1), kriteria linear (Persamaan 2), kriteria level (Persamaan 3), dan kriteria dengan preferensi linear dan area yang tidak berbeda (Persamaan 4). H(d) merupakan fungsi selisih kriteria antar alternatif, $\mathrm{d}$ menunjukkan selisih nilai kriteria atau $\{\mathrm{d}=\mathrm{f}(\mathrm{a})-\mathrm{f}(\mathrm{b})\}$, $\mathrm{p}$ menunjukkan nilai kecenderungan atas dan $\mathrm{q}$ harus merupakan nilai tetap. Perhitungan indeks preferensi dilakukan menggunakan Persamaan 7 . Pemeringkatan secara Promethee dilakukan menggunakan Persamaan 8 sampai Persamaan 10 untuk menyatakan secara berurutan fungsi Leaving Flow, Entering Flow dan Net Flow.

$$
\begin{aligned}
& \mathrm{H}(\mathrm{d})=\left\{\begin{array}{lll}
0 & \text { Jika } & d \leq q \\
1 & \text { Jika } & d>p
\end{array}\right. \\
& \mathrm{H}(\mathrm{d})=\left\{\begin{array}{c}
0 \text { Jika } d \leq 0 \\
\frac{d}{p} \text { Jika } 0 \leq d \leq p \\
1 \text { Jika } d>q
\end{array}\right. \\
& \mathrm{H}(\mathrm{d})=\left\{\begin{array}{c}
0 \text { Jika } d \leq q \\
0,5 \text { Jika } q<d \leq p \\
1 \text { Jika } d>q
\end{array}\right. \\
& \mathrm{H}(\mathrm{d})=\left\{\begin{array}{c}
0 \text { Jika } d<q \\
\frac{d-q}{p-q} \text { Jika } q<d \leq p \\
1 \text { Jika } d>q
\end{array}\right. \\
& \varphi(a, b)=\sum_{i=1}^{n} \pi i P i(a, b): \forall a, b \in A \\
& \varphi^{+}(a)=\frac{1}{n-1} \sum x \in A \varphi(a, x) \\
& \varphi^{-}(a)=\frac{1}{n-1} \sum x \in A \varphi(a, x) \\
& \varphi(a)=\varphi^{+}(a)-\varphi^{-}(a)
\end{aligned}
$$

Kriteria-kriteria dalam penelitian ini didefinisikan dengan menggunakan kriteria sesuai [17]. Kriteria C1 merupakan kriteria linear. Kriteria C2 menggunakan kriteria level. Kriteria C3 dan C4 menggunakan kriteria linear preferensi linear dan area tidak berbeda. Kriteria C5 dan C6 menggunakan kriteria quasi.

\section{Hasil dan Pembahasan}

Data tahun 2014 diolah dan diperoleh jumlah keseluruhan dari tiap kriteria setiap bulannya seperti dinyatakan dalam Tabel 1. Pada tahap ini dilakukan perbandingan antara satu alternatif dengan alternatif lainnya dengan cara mencari selisih nilai kriteria dengan cara mengurangkan alternatif satu dengan alternatif lainnya untuk mendapatkan nilai $\mathrm{d}=\mathrm{f}(\mathrm{a})-\mathrm{f}(\mathrm{b})$ dimulai dari kriteria C1 sampai C6.

Indeks preferensi kriteria $\mathrm{C} 1$ dinyatakan dalam Tabel 2. Nilai prefrensi kriteria $\mathrm{C} 1$ diperoleh dari selisih nilai kriteria pada setiap alternatif menggunakan Persamaan 2. Tabel 3 menunjukkan indeks preferensi kriteria $\mathrm{C} 2$. 
Tabel 1. Data penelitian dan kriterianya

\begin{tabular}{|c|c|c|c|c|c|c|}
\hline \multirow{4}{*}{ No Alatemative } & \multicolumn{6}{|c|}{ Kriteria } \\
\hline & $\mathrm{Cl}$ & C2 & C3 & C4 & $\mathrm{C} 5$ & C6 \\
\hline & MAX & MIN & MIN & MIN & MAX & MAX \\
\hline & III & IV & $\mathrm{V}$ & $\mathrm{V}$ & II & II \\
\hline 1 Sinaksak & 1.222 .782 .164 & 0,80 & 0,36 & 0,90 & 0 & 0 \\
\hline 2 Kerasaan & 879.250 .600 & 0,50 & 0,00 & 0,80 & 79 & 143 \\
\hline 3 Balimbingan & 1.000.367.265 & 0,50 & 0,00 & 0,85 & 37 & 0 \\
\hline 4 Tanah Jawa & 634.830 .970 & 0,77 & 0,00 & 0,90 & 42 & 299 \\
\hline 5 Jawa Tongah & 259.060.165 & 0,64 & 0,00 & 0,88 & 12 & 299 \\
\hline 6 Totap Majawa & 700.091 .670 & 0,80 & 0,00 & 0,95 & 65 & 52 \\
\hline 7 Perdagangan & 684.058 .097 & 0,75 & 0,00 & 0,99 & 15 & 0 \\
\hline 8 Tiga Balata & 670.713.652 & 0,80 & 0,69 & 0,95 & 17 & 0 \\
\hline 9 Bangun & 781.526 .815 & 0,50 & 0,00 & 0,85 & 35 & 0 \\
\hline 10 Karang Sari & 833.528 .982 & 0,95 & 0,00 & 0,95 & 146 & 165 \\
\hline 11 Sidamanik & 565. 352.192 & 0,50 & 0,00 & 0,85 & 60 & 0 \\
\hline 12 Serbelawan & 170.708.000 & 0,99 & 0,00 & 1,00 & 0 & 0 \\
\hline 13 Negeri Dolok & 559.237 .600 & 0,50 & 0,00 & 0,85 & 42 & 0 \\
\hline 14 Pematang Raya & 636. 194.370 & 0,63 & 0,00 & 0,80 & 45 & 0 \\
\hline 15 Raja Maligas & 184.139.179 & 0,50 & 0,00 & 0,90 & 0 & 0 \\
\hline 16 Tiga Dolok & 325.090 .000 & 0,80 & 0,00 & 0,80 & 15 & 0 \\
\hline 17 Huta Bayu & 117.902 .400 & 0,50 & 0,00 & 0,85 & 0 & 0 \\
\hline 18 Saran Padang & 238.878 .000 & 0,80 & 0,00 & 0,88 & 18 & 0 \\
\hline 19 Panei Tongah & 341. 709.378 & 0,58 & 0,00 & 0,95 & 10 & 0 \\
\hline 20 Raya Bayu & 260.637 .000 & 0,79 & 0,00 & 0,80 & 44 & 0 \\
\hline 21 Saribudolok & 218.850 .000 & 0,80 & 0,00 & 0,80 & 29 & 0 \\
\hline 22 Haranggaol & 112.879 .845 & 0,10 & 0,00 & 0,80 & 0 & 11 \\
\hline 23 Siboma & 191.892 .656 & 0,80 & 0,00 & 1,00 & 11 & 0 \\
\hline 24 Bah Gadu & 116.807 .363 & 0,65 & 0,00 & 0,95 & 0 & 3 \\
\hline 25 Tiga Runggu & 106.628 .337 & 0,75 & 0,00 & 0,90 & 1 & 0 \\
\hline 26 Sindar Raya & 107. 792.506 & 0,80 & 0,00 & 0,90 & 18 & 0 \\
\hline 27 Sibuntuon & 147.990 .815 & 0,65 & 0,00 & 0,90 & 19 & 0 \\
\hline 28 Merek Raya & 112.678 .299 & 0,90 & 0,00 & 0,95 & 49 & 0 \\
\hline 29 Marihat Dolok & 113.205 .576 & 0,88 & 0,00 & 0,95 & 0 & 0 \\
\hline 30 Saribu J awa & 112.491 .964 & 0,95 & 0,64 & 0,97 & 0 & 0 \\
\hline 31 Parapat & 1.737 .751 .610 & 0,50 & 0,40 & 0,83 & 60 & 0 \\
\hline 32 Panombean Par & 84.175.956 & 0,90 & 0,00 & 0,96 & 6 & 0 \\
\hline 33 Bangun Panei & 29.731. 300 & 0,75 & 0,00 & 1,00 & 0 & 0 \\
\hline 34 Sinasih & 29.731 .300 & 0,75 & 0,00 & 1,00 & 0 & 0 \\
\hline
\end{tabular}

Tabel 2. Indeks preferensi kriteria $\mathrm{C} 1$

\begin{tabular}{lrrrr}
\hline (C1) $\mathbf{p}=\mathbf{1 . 7 0 8 . 0 2 0 . 3 1 0}$ & \multicolumn{1}{c}{$\mathbf{a}$} & $\mathbf{b}$ & $\mathbf{d}$ & $\mathbf{d} \mid$ \\
\hline Sinaksak, Kerasaan & 1.222 .782 .164 & 879.250 .600 & 343.531 .564 & 343.531 .564 \\
Kerasaan, Sinaksak & 879.250 .600 & 1.222 .782 .164 & $(343.531 .564)$ & 343.531 .564 \\
Sinaksak, Balimbingan & 1.222 .782 .164 & 1.000 .367 .265 & 222.414 .899 & 222.414 .899 \\
Balimbingan, Sinaksak & 1.000 .367 .265 & 1.222 .782 .164 & $(222.414 .899)$ & 222.414 .899 \\
Sinaksak, Tanah Jawa & 1.222 .782 .164 & 634.830 .970 & 587.951 .194 & 587.951 .194 \\
Tanah Jawa, Sinaksak & 634.830 .970 & 1.222 .782 .164 & $(587.951 .194)$ & 587.951 .194 \\
Sinaksak, Jawa Tongah & 1.222 .782 .164 & 259.060 .165 & 963.721 .999 & 963.721 .999 \\
Jawa Tongah, Sinaksak & 259.060 .165 & 1.222 .782 .164 & $(963.721 .999)$ & 963.721 .999 \\
Sinaksak, Totap Majawa & 1.222 .782 .164 & 700.091 .670 & 522.690 .494 & 522.690 .494 \\
Totap Majawa, Sinaksak & 700.091 .670 & 1.222 .782 .164 & $(522.690 .494)$ & 522.690 .494 \\
Sinaksak, Perdagangan & 1.222 .782 .164 & 684.058 .097 & 538.724 .067 & 538.724 .067 \\
Perdagangan, Sinaksak & 684.058 .097 & 1.222 .782 .164 & $(538.724 .067)$ & 538.724 .067 \\
Sinaksak, Tiga Balata & 1.222 .782 .164 & 670.713 .652 & 552.068 .512 & 552.068 .512 \\
Tiga Balata, Sinaksak & 670.713 .652 & 1.222 .782 .164 & $(552.068 .512)$ & 552.068 .512 \\
Sinaksak, Bangun & 1.222 .782 .164 & 781.526 .815 & 441.255 .349 & 441.255 .349 \\
Bangun, Sinaksak & 781.526 .815 & 1.222 .782 .164 & $(441.255 .349)$ & 441.255 .349 \\
Sinaksak, Karang Sari & 1.222 .782 .164 & 833.528 .982 & 389.253 .182 & 389.253 .182 \\
Karang Sari, Sinaksak & 833.528 .982 & 1.222 .782 .164 & $(389.253 .182)$ & 389.253 .182 \\
Sinaksak, Sidamanik & 1.222 .782 .164 & 565.352 .192 & 657.429 .972 & 657.429 .972 \\
\hline
\end{tabular}

Nilai kriteria C2 diperoleh dari selisih nilai kriteria pada setiap alternatif menggunakan Persamaan 3. Tabel 4 menunjukkan indeks preferensi kriteria C3. Nilai preferensi kriteria $\mathrm{C} 3$ diperoleh dari selisih nilai kriteria
Tabel 3. Indeks preferensi kriteria $\mathrm{C} 2$

\begin{tabular}{lccccc}
\hline (C2) $\mathbf{p = 0 , 8 9} \mathbf{q}=\mathbf{0 , 4 5}$ & $\mathbf{a}$ & $\mathbf{b}$ & $\mathbf{d}$ & $\mathbf{| d |}$ & $\mathbf{P}$ \\
\hline Sinaksak, Kerasaan & 0,80 & 0,50 & 0,30 & 0,30 & 0 \\
Kerasaan, Sinaksak & 0,50 & 0,80 & $(0,30)$ & 0,30 & 0 \\
Sinaksak, Balimbingan & 0,80 & 0,50 & 0,30 & 0,30 & 0 \\
Balimbingan, Sinaksak & 0,50 & 0,80 & $(0,30)$ & 0,30 & 0 \\
Sinaksak, Tanah Jawa & 0,80 & 0,77 & 0,03 & 0,03 & 0 \\
Tanah Jawa, Sinaksak & 0,77 & 0,80 & $(0,03)$ & 0,03 & 0 \\
Sinaksak, Jawa Tongah & 0,80 & 0,64 & 0,16 & 0,16 & 0 \\
Jawa Tongah, Sinaksak & 0,64 & 0,80 & $(0,16)$ & 0,16 & 0 \\
Sinaksak, Totap Majawa & 0,80 & 0,80 & 0,00 & 0,00 & 0 \\
Totap Majawa, Sinaksak & 0,80 & 0,80 & 0,00 & 0,00 & 0 \\
Sinaksak, Perdagangan & 0,80 & 0,75 & 0,05 & 0,05 & 0 \\
Perdagangan, Sinaksak & 0,75 & 0,80 & $(0,05)$ & 0,05 & 0 \\
Perdagangan, Sinaksak & 0,75 & 0,80 & $(0,05)$ & 0,05 & 0 \\
Sinaksak, Tiga Balata & 0,80 & 0,80 & 0,00 & 0,00 & 0 \\
Tiga Balata, Sinaksak & 0,80 & 0,80 & 0,00 & 0,00 & 0 \\
Sinaksak, Bangun & 0,80 & 0,50 & 0,30 & 0,30 & 0 \\
Bangun, Sinaksak & 0,50 & 0,80 & $(0,30)$ & 0,30 & 0 \\
Sinaksak, Karang Sari & 0,80 & 0,95 & $(0,15)$ & 0,15 & 0 \\
... & & & & & \\
Sinasin, Bangun Panei & 0,75 & 0,75 & 0,00 & 0,00 & 0 \\
\hline
\end{tabular}

Tabel 4. Indeks preferensi kriteria $\mathrm{C} 3$

\begin{tabular}{lrrccc}
\hline (C3) p=1 q=0,30 & \multicolumn{1}{c}{$\mathbf{~}$} & \multicolumn{1}{c}{$\mathbf{b}$} & $\mathbf{d}$ & $\mathbf{~ d ~} \mid$ & $\mathbf{P}$ \\
\hline Sinaksak, Kerasaan & 0,36 & 0 & 0,36 & 0,36 & 0,0857 \\
Kerasaan, Sinaksak & 0 & 0,36 & $(0,36)$ & 0,36 & 0,0857 \\
Sinaksak, Balimbingan & 0,36 & 0 & 0,36 & 0,36 & 0,0857 \\
Balimbingan, Sinaksak & 0 & 0,36 & $(0,36)$ & 0,36 & 0,0857 \\
Sinaksak, Tanah J awa & 0,36 & 0 & 0,36 & 0,36 & 0,0857 \\
Tanah J awa, Sinaksak & 0 & 0,36 & $(0,36)$ & 0,36 & 0,0857 \\
Sinaksak, Jawa Tongah & 0,36 & 0 & 0,36 & 0,36 & 0,0857 \\
Jawa Tongah, Sinaksak & 0 & 0,36 & $(0,36)$ & 0,36 & 0,0857 \\
Sinaksak, Totap Majawa & 0,36 & 0 & 0,36 & 0,36 & 0,0857 \\
Totap Majawa, Sinaksak & 0 & 0,36 & $(0,36)$ & 0,36 & 0,0857 \\
Sinaksak, Perdagangan & 0,36 & 0 & 0,36 & 0,36 & 0,0857 \\
Perdagangan, Sinaksak & 0 & 0,36 & $(0,36)$ & 0,36 & 0,0857 \\
Sinaksak, Tiga Balata & 0,36 & 0,69 & $(0,34)$ & 0,34 & 0,0571 \\
Tiga Balata, Sinaksak & 0,69 & 0,36 & 0,34 & 0,34 & 0,0571 \\
Sinaksak, Bangun & 0,36 & 0 & 0,36 & 0,36 & 0,0857 \\
Bangun, Sinaksak & 0 & 0,36 & $(0,36)$ & 0,36 & 0,0857 \\
Sinaksak, Karang Sari & 0,36 & 0 & 0,36 & 0,36 & 0,0857 \\
Karang Sari, Sinaksak & 0 & 0,36 & $(0,36)$ & 0,36 & 0,0857
\end{tabular}

...

$\cdots$

Panambean Panei, Sinasit $\quad \begin{array}{lllll}0 & 0 & 0,00 & 0,00 & 0\end{array}$

Sinasih, Panambean Pane $\begin{array}{lllll}0 & 0 & 0,00 & 0,00 & 0\end{array}$

$\begin{array}{llllll}\text { Bangun Panei, Sinasih } & 0 & 0 & 0,00 & 0,00 & 0\end{array}$

$\begin{array}{llllll}\text { Sinasih, Bangun Panei } & 0 & 0 & 0,00 & 0,00 & 0\end{array}$

pada setiap alternatif menggunakan Persamaan 4 . Tabel 5 menunjukkan indeks preferensi kriteria $\mathrm{C} 4$. Nilai preferensi ini diperoleh dari selisih nilai kriteria pada setiap alternatif menggunakan Persamaan 4. Tabel 6 menunjukkan indeks preferensi kriteria C5. Nilai preferensi ini diperoleh dari selisih nilai kriteria pada setiap alternatif menggunakan Persamaan 1. Tabel 7 menunjukkan indeks preferensi kriteria C6. Nilai preferensi ini diperoleh dari selisih nilai kriteria pada setiap alternatif menggunakan Persamaan 1. 
Tabel 5. Indeks preferensi kriteria $\mathrm{C} 4$

\begin{tabular}{|c|c|c|c|c|c|}
\hline (C4) $p=1 q=0,19$ & $\mathbf{a}$ & $\mathbf{b}$ & d & $|\mathbf{d}|$ & $\mathbf{P}$ \\
\hline Sinaksak, Kerasaan & 0,90 & 0,80 & 0,10 & 0,10 & 0 \\
\hline Kerasaan, Sinaksak & 0,80 & 0,90 & $(0,10)$ & 0,10 & 0 \\
\hline Sinaksak, Balimbingan & 0,90 & 0,85 & 0,05 & 0,05 & 0 \\
\hline Balimbingan, Sinaksak & 0,85 & 0,90 & $(0,05)$ & 0,05 & 0 \\
\hline Sinaksak, Tanah Jawa & 0,90 & 0,90 & 0,00 & 0,00 & 0 \\
\hline Tanah Jawa, Sinaksak & 0,90 & 0,90 & 0,00 & 0,00 & 0 \\
\hline Sinaksak, Jawa Tongah & 0,90 & 0,88 & 0,02 & 0,02 & 0 \\
\hline Jawa Tongah, Sinaksak & 0,88 & 0,90 & $(0,02)$ & 0,02 & 0 \\
\hline Sinaksak, Totap Majawa & 0,90 & 0,95 & $(0,05)$ & 0,05 & 0 \\
\hline Totap Majawa, Sinaksak & 0,95 & 0,90 & 0,05 & 0,05 & 0 \\
\hline Sinaksak, Perdagangan & 0,90 & 0,99 & $(0,09)$ & 0,09 & 0 \\
\hline Perdagangan, Sinaksak & 0,99 & 0,90 & 0,09 & 0,09 & 0 \\
\hline Sinaksak, Tiga Balata & 0,90 & 0,95 & $(0,05)$ & 0,05 & 0 \\
\hline Tiga Balata, Sinaksak & 0,95 & 0,90 & 0,05 & 0,05 & 0 \\
\hline Sinaksak, Bangun & 0,90 & 0,85 & 0,05 & 0,05 & 0 \\
\hline Bangun, Sinaksak & 0,85 & 0,90 & $(0,05)$ & 0,05 & 0 \\
\hline Sinaksak, Karang Sari & 0,90 & 0,95 & $(0,05)$ & 0,05 & 0 \\
\hline Karang Sari, Sinaksak & 0,95 & 0,90 & 0,05 & 0,05 & 0 \\
\hline Sinaksak, Sidamanik & 0,90 & 0,85 & 0,05 & 0,05 & 0 \\
\hline Sidamanik, Sinaksak & 0,85 & 0,90 & $(0,05)$ & 0,05 & 0 \\
\hline \multicolumn{6}{|l|}{$\cdots$} \\
\hline \multicolumn{6}{|l|}{$\cdots$} \\
\hline \multicolumn{6}{|l|}{$\cdots$} \\
\hline Panambean Panei, Sinasih & 0,96 & 1,00 & $-0,04$ & 0,04 & 0 \\
\hline Sinasih, Panambean Panei & 1,00 & 0,96 & 0,04 & 0,04 & 0 \\
\hline Bangun Panei, Sinasih & 1,00 & 1,00 & 0,00 & 0,00 & 0 \\
\hline Sinasih, Bangun Panei & 1,00 & 1,00 & 0,00 & 0,00 & 0 \\
\hline
\end{tabular}

Tabel 6. Indeks preferensi kriteria C5

\begin{tabular}{lrrrrl}
\hline (C5) q= 140 & a & b & d & d & P \\
\hline Sinaksak, Kerasaan & 0 & 79 & -79 & 79 & 0 \\
Kerasaan, Sinaksak & 79 & 0 & 79 & 79 & 0 \\
Sinaksak, Balimbingan & 0 & 37 & -37 & 37 & 0 \\
Balimbingan, Sinaksak & 37 & 0 & 37 & 37 & 0 \\
Sinaksak, Tanah Jawa & 0 & 42 & -42 & 42 & 0 \\
Tanah Jawa, Sinaksak & 42 & 0 & 42 & 42 & 0 \\
Sinaksak, Jawa Tongah & 0 & 12 & -12 & 12 & 0 \\
Jawa Tongah, Sinaksak & 12 & 0 & 12 & 12 & 0 \\
Sinaksak, Totap Majawa & 0 & 65 & -65 & 65 & 0 \\
Totap Majawa, Sinaksak & 65 & 0 & 65 & 65 & 0 \\
Sinaksak, Perdagangan & 0 & 15 & -15 & 15 & 0 \\
Perdagangan, Sinaksak & 15 & 0 & 15 & 15 & 0 \\
Sinaksak, Tiga Balata & 0 & 17 & -17 & 17 & 0 \\
Tiga Balata, Sinaksak & 17 & 0 & 17 & 17 & 0 \\
Sinaksak, Bangun & 0 & 35 & -35 & 35 & 0 \\
Bangun, Sinaksak & 35 & 0 & 35 & 35 & 0 \\
.. & & & & & \\
Panambean Panei, Sinasih & 6 & 0 & 6 & 6 & 0 \\
Sinasih, Panambean Panei & 0 & 6 & -6 & 6 & 0 \\
Bangun Panei, Sinasih & 0 & 0 & 0 & 0 & 0 \\
Sinasih, Bangun Panei & 0 & 0 & 0 & 0 & 0 \\
\hline
\end{tabular}

Setelah nilai preferensi dari setiap kriteria diperoleh, nilai preferensi dari setiap kriteria dijumlahkan dan dibagi dengan jumlah kriteria yang ada menghasilkan indeks preferensi menggunakan Persamaan 5. Nilai indeks preferensi untuk tiap alternatif dinyatakan dalam Tabel 8.

Hasil pemeringkatan secara Promethee menggunakan Persamaan 6, Persamaan 7 dan Persamaan 8 dinyatakan dalam Tabel 9. Tahap pemeringkatan terbagi jadi 2 (dua), yaitu Promethee I (pemeringkatan parsial yaitu pemeringkatan
Tabel 7. Indeks preferensi kriteria C6

\begin{tabular}{lrrrrr}
\hline (C6) q= 299 & a & b & d & |d & P \\
\hline Sinaksak, Kerasaan & 0 & 143 & -143 & 143 & 0 \\
Kerasaan, Sinaksak & 143 & 0 & 143 & 143 & 0 \\
Sinaksak, Balimbingan & 0 & 0 & 0 & 0 & 0 \\
Balimbingan, Sinaksak & 0 & 0 & 0 & 0 & 0 \\
Sinaksak, Tanah Jawa & 0 & 299 & -299 & 299 & 0 \\
Tanah Jawa, Sinaksak & 299 & 0 & 299 & 299 & 1 \\
Sinaksak, Jawa Tongah & 0 & 299 & -299 & 299 & 0 \\
Jawa Tongah, Sinaksak & 299 & 0 & 299 & 299 & 1 \\
Sinaksak, Totap Majawa & 0 & 52 & -52 & 52 & 0 \\
Totap Majawa, Sinaksak & 52 & 0 & 52 & 52 & 0 \\
Sinaksak, Perdagangan & 0 & 0 & 0 & 0 & 0 \\
Perdagangan, Sinaksak & 0 & 0 & 0 & 0 & 0 \\
Sinaksak, Tiga Balata & 0 & 0 & 0 & 0 & 0 \\
.. & & & & & \\
Panambean Panei, Sinasih & 0 & 0 & 0 & 0 & 0 \\
Sinasih, Panambean Panei & 0 & 0 & 0 & 0 & 0 \\
Bangun Panei, Sinasih & 0 & 0 & 0 & 0 & 0 \\
Sinasih, Bangun Panei & 0 & 0 & 0 & 0 & 0 \\
\hline
\end{tabular}

berdasarkan Leaving Flow dan Entering Flow dengan Persamaan 6 dan Persamaan 7), dan Promethee II (pemeringkatan lengkap) yaitu pemeringkatan berdasarkan nilai Net Flow dengan Persamaan 8.

Berdasarkan Tabel 9, dapat dilihat bahwa hasil pemeringkatan dari 34 alternatif menunjukkan unit dengan nilai Net Flow tertinggi adalah unit Tanah Jawa dengan nilai 0,16274 . Unit ini direkomendasikan sebagai unit produksi terbaik di PDAM Tirta Lihou. Grafik peringkat unit kerja PDAM Tirta Lihou selama tahun 2014 ini ditunjukkan dalam Gambar 1.

SPK untuk merekomendasikan unit terbaik pada PDAM Tirta Lihou ini telah dapat bekerja menggunakan Promethee, seperti halnya [3]-[6], [11][13] berdasarkan laporan capaian target luaran. Sistem telah dapat melakukan pemeringkatan dari 34 alternatif, yang sesuai dengan [16], menggunakan 6 kriteria dan 4 tipe kriteria dalam [17]. Sistem ini dapat menghasilkan keputusan yang lebih baik daripada sistem penilaian sebelumnya yang bersifat konvensional, sehingga pimpinan PDAM Tirta Lihou dapat memilih unit terbaik secara objektif. Perbaikan sistem dapat dilakukan dengan menambahkan AHP untuk menentukan bobot dan hierarki kriteria sehingga menghasilkan peringkat yang lebih stabil seperti dalam Lemantara dkk [2].

\section{KESIMPULAN}

Metode Promethee dapat diimplementasikan untuk merekomendasikan unit terbaik di PDAM Tirta Lihou, Kabupaten Simalungun. Metode ini menjadi salah satu alternatif dalam menyelesaikan kasus yang bersifat multi kompleks yang terdiri dari banyak alternatif, dan banyak kriteria.

\section{UCAPAN TERIMA KASIH}

Terima kasih disampaikan kepada pimpinan PDAM Tirta Lihou, Kabupaten Simalungun yang telah mendukung penelitian ini. 


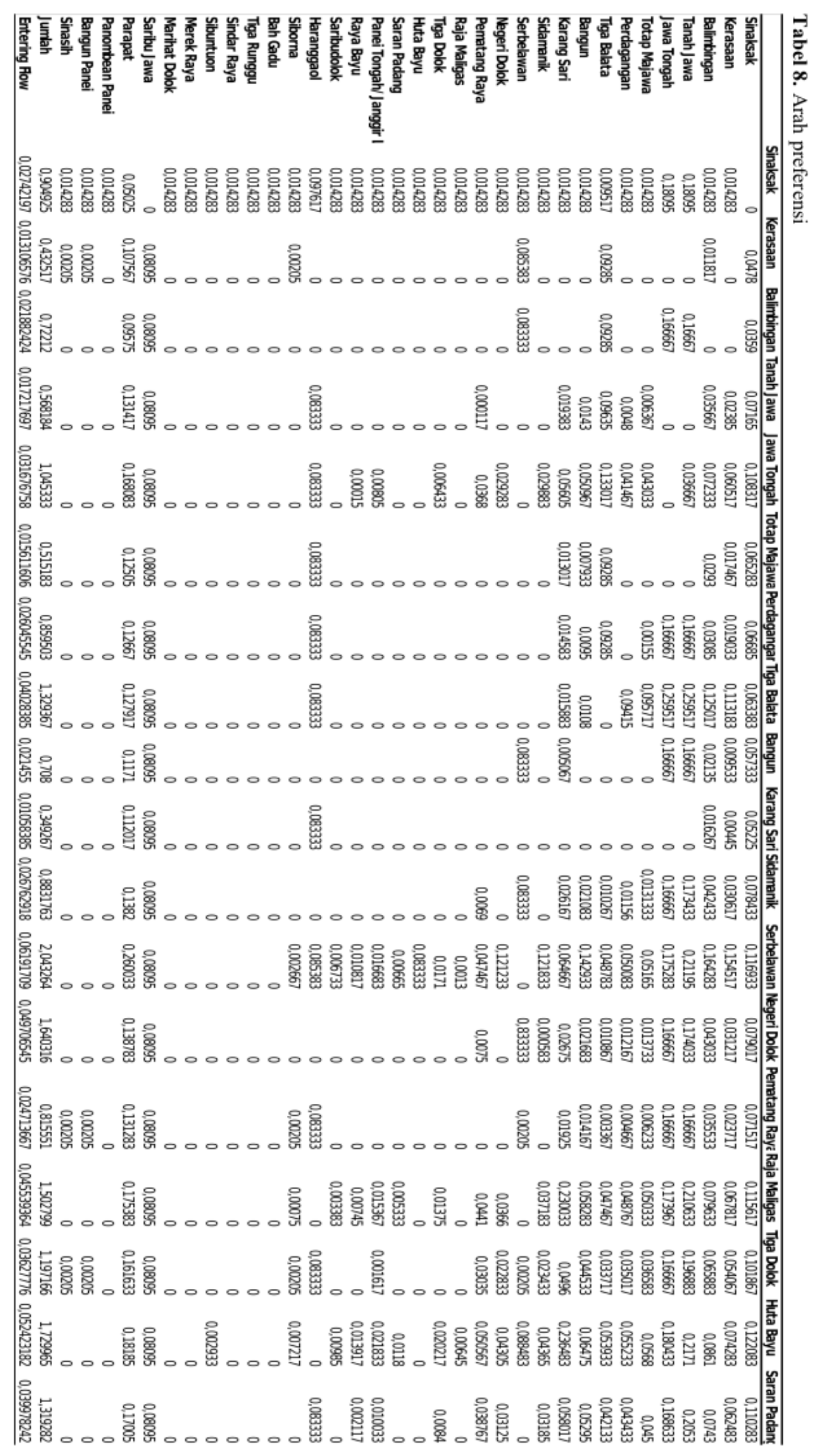


Tabel 9. Hasil pemeringkatan berdasarkan net glow

\begin{tabular}{lcllc}
\multicolumn{1}{c}{ Alternative } & $\begin{array}{c}\text { Leaving } \\
\text { Flow }\end{array}$ & $\begin{array}{c}\text { Entering } \\
\text { Flow }\end{array}$ & Net Flow & Peringkat \\
\hline Sinaksak & 0,0979934 & 0,02742197 & 0,070571 & 5 \\
Kerasaan & 0,0592445 & 0,013106576 & 0,046138 & 7 \\
Balimbingan & 0,0700995 & 0,021882424 & 0,048217 & 6 \\
Tanah Jawa & 0,1799577 & 0,017217697 & 0,16274 & 1 \\
Jawa Tongah & 0,1568835 & 0,031676758 & 0,125207 & 2 \\
Totap Majawa & 0,0437399 & 0,015611606 & 0,028128 & 8 \\
Perdagangan & 0,0424599 & 0,026045545 & 0,016414 & 10 \\
Tiga Balata & 0,0553581 & 0,040283848 & 0,015074 & 11 \\
Bangun & 0,0476525 & 0,021454545 & 0,026198 & 9 \\
Karang Sari & 0,0975828 & 0,010583848 & 0,086999 & 4 \\
Sidamanik & 0,0304393 & 0,026762918 & 0,003676 & 13 \\
Serbelawan & 0,0493019 & 0,061917091 & $-0,01262$ & 14 \\
Negeri Dolok & 0,03085 & 0,049706545 & $-0,01886$ & 16 \\
Pematang Raya & 0,0363172 & 0,024713667 & 0,011604 & 12 \\
Raja Maligas & 0,0066531 & 0,045539364 & $-0,03889$ & 24 \\
Tiga Dolok & 0,0166091 & 0,036277758 & $-0,01967$ & 17 \\
Huta Bayu & 0,0068782 & 0,052423182 & $-0,04554$ & 30 \\
Saran Padang & 0,0116414 & 0,039978242 & $-0,02834$ & 19 \\
Panei Tongah/ & 0,0174702 & 0,035343485 & $-0,01787$ & 15 \\
Janggir Leto & & & & \\
Raya Bayu & 0,0129879 & 0,03913697 & $-0,02615$ & 18 \\
Saribudolok & 0,0109445 & 0,041275727 & $-0,03033$ & 20 \\
Haranggaol & 0,0675968 & 0,103462576 & $-0,03587$ & 22 \\
Siborna & 0,0098081 & 0,042930273 & $-0,03312$ & 21 \\
Bah Gadu & 0,0068454 & 0,052116576 & $-0,04527$ & 29 \\
Tiga Runggu & 0,006653 & 0,053482667 & $-0,04683$ & 32 \\
Sindar Raya & 0,0066667 & 0,047787282 & $-0,04112$ & 27 \\
Sibuntuon & 0,0077741 & 0,045419758 & $-0,03765$ & 23 \\
Merek Raya & 0,0067384 & 0,047789424 & $-0,04105$ & 26 \\
Marihat Dolok & 0,0069358 & 0,052663667 & $-0,04573$ & 31 \\
Saribu Jawa & 0,0791722 & 0,120111758 & $-0,04094$ & 25 \\
Parapat & 0,1573329 & 0,039913636 & 0,117419 & 3 \\
Panombean & 0,0064535 & 0,050355515 & $-0,0439$ & 28 \\
Panei & & & & \\
Bangun Panei & 0,006505 & 0,06074897 & $-0,05424$ & 33 \\
Sinasih & 0,006505 & 0,060909576 & $-0,0544$ & 34 \\
\hline & & & & \\
\hline
\end{tabular}

\section{Daftar Pustaka}

[1] I. H. Firdaus, G. Abdillah, F. Renaldi, "Sistem Pendukung Keputusan Penentuan Karyawan Terbaik Menggunakan Metode Ahp Dan Topsis," in Seminar Nasional Teknologi Informasi dan Komunikasi 2016 (SENTIKA 2016) , 18-19 Maret 2016.

[2] J. Lemantara, N. A. Setiawan, and M. N. Aji, "Rancang Bangun Sistem Pendukung Keputusan Pemilihan Mahasiswa Berprestasi Menggunakan Metode AHP dan Promethee," Jurnal Nasional Teknik Elektro dan Teknologi Informasi (JNTETI), vol. 2, no. 1, 2013.

[3] F. S. Priyanto, B. Harijanto, and Y. Watequlis, "Sistem Pendukung Keputusan Pemilihan Guru Berprestasi Menggunakan Metode Promethee," Jurnal Informatika Polinema, vol. 3, no.4, pp. 2328, 2017.

[4] O. A. Asmara, and A. Susanto, "Sistem Pendukung Keputusan Penerimaan Karyawan Pada Saudara Group Semarang Menggunakan Metode Promethee," Skripsi, Universitas Dian Nuswantoro, Juli 2013.

[5] R. Hidayat, "Menentukan Promosi Jabatan Karyawan Dengan Menggunakan Metode Profile Matching Dan Metode Promethee," Indonesian

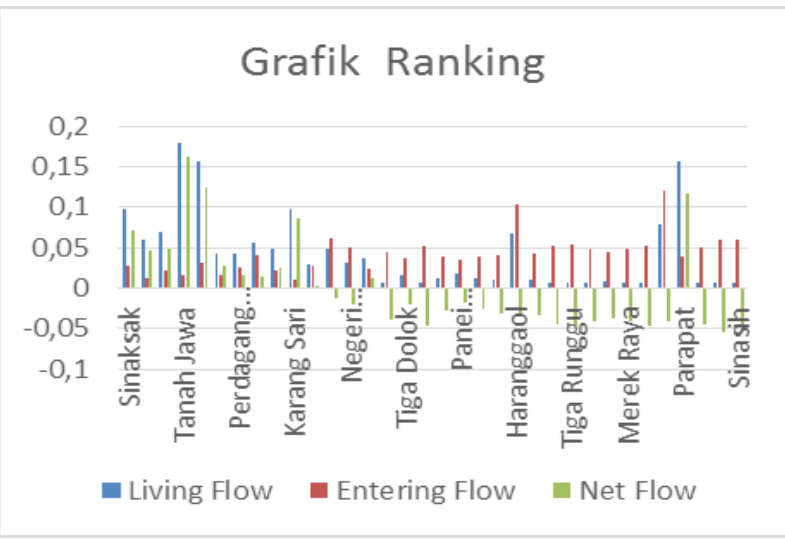

Gambar 1. Grafik peringkat unit kerja PDAM

Journal on Software Engineering, vol. 2, no. 1, 2016.

[6] C. W. Andi, "Sistem Pendukung Keputusan Penilaian Kinerja Pegawai Menggunakan Metode Promethee Di Museum Ranggawarsita Semarang," Skripsi, Universitas Dian Nuswantoro, 2015.

[7] S. Abadi, and F. Latifah, "Decision Support System Penilaian Kinerja Karyawan pada Perusahaan dengan Menggunakan Metode Simple Additive Weighting," Jurnal TAM (Technology Acceptance Model), vol. 6, pp. 37-43, 2017.

[8] A. G. Anto, H. Mustafidah, and A. Suyudi, "Sistem Pendukung Keputusan Penilaian Kinerja Karyawan Menggunakan Metode SAW," Jurnal Informatik (JUITA), vol. 3, no. 4, pp. 193-200, 2015.

[9] A. Suryana, E. Yulianto, and K. D. Pratama, "Perancangan Sistem Pendukung Keputusan Penilaian Prestasi Pegawai Menggunakan Metode SAW, AHP, dan TOPSIS," Jurnal Ilmiah Teknologi Informasi Terapan, vol. 3, no. 2, 2017.

[10] R. Irawan, and S. Winiarti, "Sistem Pendukung Keputusan Pemilihan Lokasi dan Evaluasi Lokasi Pemasaran Produk (Gula) Menggunakan Metode AHP (Studi Kasus: PT. Madubaru)," Jurnal Informatika, vol. 9, no. 2, Juli 2015.

[11] G. Gunawan, and S. Astuti, "Sistem Pendukung Keputusan Pemilihan Gadget Android Menggunakan Metode PROMETHEE," Techno. Com., vol. 12, no. 2, pp. 104-116, Mei 2013.

[12] R. Hanifah, "Implementasi Metode PROMETHEE Dalam Menentukan Penerimaan Kredit Usaha Rakyat(KUR)," Jurnal Teknologi, vol. 8, no. 2, pp. 169-177, Desember 2015.

[13] M. Muhardiansyah, Z. Arifin, and S. Maharani, "Perangkat Lunak Bantu Pemilihan Komputer Menggunakan Metode PROMETHEE," in Prosiding Seminar Ilmu Komputer dan Teknologi Informasi (SAKTI), vol. 1, no. 2, pp. 71-76, September 2016.

[14] A. Nurzahputra, A. R. Pranata, A. Puwinarko, "Sistem Pendukung Keputusan Pemilihan Line-up Pemain Sepak Bola Menggunakan Metode Fuzzy Multiple Attribute Decision Making dan K-Means Clustering," Jurnal Teknologi dan Sistem Komputer, vol. 5, no. 3, pp. 106-109, 2017. 
[15] E. Puspitarini, K. Kusrini, and E. T. Lutfi, "Sistem Penunjang Keputusan Pemberian Kredit Menggunakan Logika Fuzzy," in Proc. Konferensi Nasional Sistem dan Informatik (KNS\&I), 2015, pp. 927-932.

[16] P. Mursanto, and W. Sari, "Defining Relative Qualities of Object Oriented Design
Implementations using AHP and Promethee," in Proc. International Symposium on The Analytic Hierarchy Process, 2011.

[17] J. P. Brans, and Ph. Vincke, "A preference ranking organization method: The PROMETHEE methods," Management Science, vol. 31, pp. 647656, 1984. 